\title{
UPAYA PENINGKATKAN HASIL BELAJAR SISWA PADA PELAJARAN SENI BUDAYA ARANSEMEN MUSIK MANCANEGARA DENGAN MEDIA PEMBELAJARAN AUDIO VISUAL
}

\author{
Eni Sukmawati ${ }^{\left.a^{*}\right)}$ \\ ${ }^{a)}$ SMAN 9 Kota Bogor, Bogor, Indonesia \\ ${ }^{*}$ e-mail korespondensi: aldinadenisyaaa@ gmail.com
}

\begin{abstract}
Abstrak
Riwayat Artikel

diterima 23 September 2020 direvisi 13 Oktober 2020

disetujui 12 Nopember 2020

Penelitian ini beranjak dari fenomena yang terjadi di kelas bahwa kurangnya pemahaman tentang mengaransemen sebuah lagu menggunakan media audiovisual. Penelitian ini bertujuan Untuk (1) mengetahui media pembelajaran Audio Visual dapat meningkatkan hasil belajar peserta didik tentang Aransemen Musik Mancanegara. (2) Untuk menggambarkan proses peningkatan hasil belajar peserta didik tentang Aransemen Musik Mancanegara sebelum dan sesudah menggunakan media pembelajaran audio visual. (3) Untuk mengukur besarnya peningkatan hasil belajar peserta didik tentang Aransemen Musik Mancanegara setelah menggunakan media pembelajaran audio visual. Media pembelajaran audio visual dapat meningkatan hasil belajar pesertsa didik pada materi Aransemen Musik Mancanegara di kelas XII IPA 3 SMA Negeri 9 Kota Bogor.
\end{abstract}

Kata kunci: media pembelajaran; seni budaya; aransemen musik

\begin{abstract}
EFFORTS TO IMPROVE STUDENT LEARNING OUTCOMES IN INTERNATIONAL MUSIC ARRANGEMENT CULTURAL ARTS LESSONS USING AUDIO VISUAL LEARNING MEDIA

Abstract. This research departs from the phenomenon that occurs in class, namely the lack of understanding of composing a song using audiovisual media. This study aims to (1) find out that audio visual learning media can improve student learning outcomes about international music arrangements. (2) To describe the process of improving student learning outcomes about International Music Arrangements before and after using audio-visual learning media. (3) To measure the magnitude of the increase in student learning outcomes about International Music Arrangements after using audio-visual learning media. Audio-visual learning media can improve student learning outcomes on International Music Arrangement material in SMA Negeri 9 Bogor.
\end{abstract}

Keywords: instructional Media; art and culture; music arrangement

\section{PENDAHULUAN}

Pendidikan memiliki peran yang sangat penting bagi manusia dalam kegiatan sehari-hari, karena pendidikan sangat besar pengaruhnya terhadap perkembangan manusia dalam seluruh aspek kehidupan. Manusia tumbuh dan berkembang melalui belajar. Dalam belajar banyaak faktor yang menentukan keberhasilan belajar. Keberhasilan belajar tidak terlepas dari peran guru dalam proses pembelajaran, karena dalam proses pembelajaran guru menjadi peran utama dalam menciptakan situasi yang edukatif, yaitu interaksi antara guru dan peserta didk, peserta didik dengan peserta didk, dan dengan sumber pembelajaran dalam menunjang tercapainya tujuan pembelajaran dan hasil belajar. Hasil belajar menurut Syaeful dan Aswan [1] setiap proses belajar selalu menghasilkan hasil belajar. Masalah yang dihadapi adalah sampai ditingkat mana prestasi belajar yang dicapai. Hasil belajar menurut Bloom [2] hasil belajar mencakup kemampuan kognitif, afektif dan psikomotorik, hal yang sama juga diungkapkan oleh Agus [3] hasil belajar adalah perubahan tingkah laku secara keseluruhan bukan hanya salah satu aspek potensi manusia saja. Setiap organisasi pendidikan tentu melaksanakan program yang dimulai dari tahap perencanaan sampai pada evaluasi [4].

Di SMAN 9 Kota Bogor pada mata pelajaran Seni Budaya tentang Aransemen Musik Mancanegara. KKM yang telah ditentukan adalah 75 namun nilai peserta didik selalu rendah. Berdasarkan tes awal yang telah dilaksanakan rata-rata memperoleh nilai 66,03. Dari 34 peserta didik hanya 8 peserta didik atau $23,53 \%$ yang memiliki nilai di atas KKM yang telah ditentukan dan 26 pesert didik $(76,47 \%)$ di bawah KKM. Hal ini disebabkan guru mengajar dengan menggunakan konfensional, metode yang domimam adalah menggunakan metode ceramah, komunikasi hanya satu arah, peserta didik dijadikan obyek pendengar, peserta didik dibuat pasif dalam KBM dan guru tidak menggunakan media pembelajaran. Tujuan penelitian ini adalah Untuk mengetahui media pembelajaran Audio Visual dapat meningkatkan hasil belajar peserta didik tentang Aransemen Musik Mancanegara di kelas XII IPA 3 SMA Neegeri 9 Kota Bogor. Untuk menggambarkan proses peningkatan hasil belajar peserta didik tentang Aransemen Musik Mancanegara sebelum dan sesudah menggunakan 
media pembelajaran audio visual di kelas XII IPA 3 SMA Negeri 9 Kota Bogor. Mengukur besarnya peningkatan hasil belajar peserta didik tentang Aransemen Musik Mancanegara setelah menggunakan media pembelajaran audio visual di Kelas XII IPA 3 SMA Negeri 9 Kota Bogor. Hasil penelitian ini diharapkan bermanfaat untuk peserta didik, guru dan peningkatan kualitas pembelajaran di SMA Negeri 9 kota Bogor.

Gagne (dalam Ngalim Purwanto[5]) menyatakan bahwa belajar terjadi apabila suatu situasi stimulus bersama dengan isi ingatan mempengaruhi siswa sedemikian rupa sehingga perbuatannya (performance-nya) berubah dari waktu sebelum ia mengalami situasi itu ke waktu sesudah ia mengalami situasi tadi. Tidak jauh berbeda, Morgan (dalam Ngalim [5]) merumuskan bahwa belajar adalah setiap perubahan yang relatif menetap dalam tingkah laku yang terjadi sebagai suatu hasil dari latihan atau pengalaman. Aktivitas berasal dari kata aktif yang berarti kegiatan, kesibukan (Poerwadarminta [6]). Dalam proses pembelajaran siswa dituntut untuk selalu aktif secara fisik, intelektual dan emosional. Guru harus memperhatikan keaktifan siswa dalam pembelajaran. Terutama sikap aktif yang positif dari siswa, karena sangat berpengaruh terhadap kelancaran proses belajar mengajar sehingga dapat diperoleh hasil yang maksimal. Setiap guru memiliki pandangan yang berbeda dalam menyatakan suatu proses belajar mengajar dinyatakan berhasil atau tidak. Kurikulum merupakan salah satu pedoman yang dapat digunakan untuk menyelaraskan berbagai macam persepsi itu. Hasil belajar adalah sesuatu yang didapat setelah melalui proses belajar itu sendiri.

Audio visual adalah video yang menampilkan bentuk suara dan gambar, Aristo Rahadi [7]. Djamarah [8] mengatakan bahwa metode bervariasi adalah metode pembelajaran yang dalam proses belajar mengajar meliputi variasi dalam gaya mengajar, variasi dalam menggunakan media dan bahan pengajaran, serta variasi dalam interaksi antara guru dan siswa. Dalam pelaksanaanya guru sudah melakukan 7 macam gaya mengajar menurut Marno dan Idris, yaitu (1) variasi suara guru, (2) variasi mimik dan gerak, (3) perubahan posisi, (4) kesenyapan atau diam sejenak, (5) pemusatan perhatian, (6) pemusatan perhatian, (7) kontak pandang. Variasi lain yang dilakukan guru yaitu menggunakan variasi media selain penggunaan media audio visual sebagai media utama, guru juga menggunakan media lain berupa lembar partitur. Variasi lain yang tidak kalah penting yaitu variasi pola interaksi. Guru menggunakan lebih dari satu variasi pola interkasi salah satunya yaitu demonstrasi dan tanya jawab.

\section{METODE PENELITIAN}

Penelitian ini dilaksanakan Di Kelas XII IPA 3 Semester 2 Tahun Pelajaran 2017-1018 SMA Negeri 9 Kota Bogor. Ketika guru mengajar tentang Aransemen Musik Mancanegara KKM telah ditentukan 75, materi Aransemen Musik Mancanegara bahasannya cukup banyak/luas, Untuk mendapatkan data yang diperlukan oleh penulis, digunakan instrumen pengumpulan data dengan Tes Uji Kompetensi dan Lembar Observasi.

Penelitian yang dilakukan adalah Penelitian tindakan kelas yang merupakan proses pengkajian melalui sistem yang berdaur ulang dari berbagai kegiatan pembelajaran yang terdiri atas empat tahap yang saling terkait dan berkesinambungan. Tahap-tahap tersebut yaitu: (1) perencanaan (planning), (2) pelaksanaan tindakan (action), (3) pengamatan (observing), dan (4) refleksi (reflecting).

Rencana tindakan ini disusun untuk dua siklus sesuai dengan perkiraan terpecahnya masalah ini secara optimal, Analisis data yang digunakan dalam penelitian ini yaitu teknik kuantitatif yang berupa perhitungan dan teknik kualitatif yang berupa uraian. Setelah data terkumpul dan diperiksa, bila memenuhi persyaratan maka data tersebut ditabulasikan dalam tabel yang telah siap untuk pengolahan. Setelah dicek kebenarannya kemudian dihitung persentasenya. Untuk mengetahui keefektifan suatu metode dalam kegiatan pembelajaran, perlu dilakukan analisis data. Pada penelitian tindakan kelas ini, digunakan analisis deskripsi kualitatif, yaitu suatu metode penelitian yang bersifat menggambarkan kenyataan atau fakta sesuai dengan data yang diperoleh dengan tujuan untuk mengetahui hasil belajar yang dicapai peserta didik, juga untuk mengetahui respon peserta didik terhadap kegiatan pembelajaran serta aktifitas peserta didik selama proses pembelajaran berlangsung.

Penelitian Tindakan Kelas ini menggunakan desain penelitian model desain Model John Elliot.

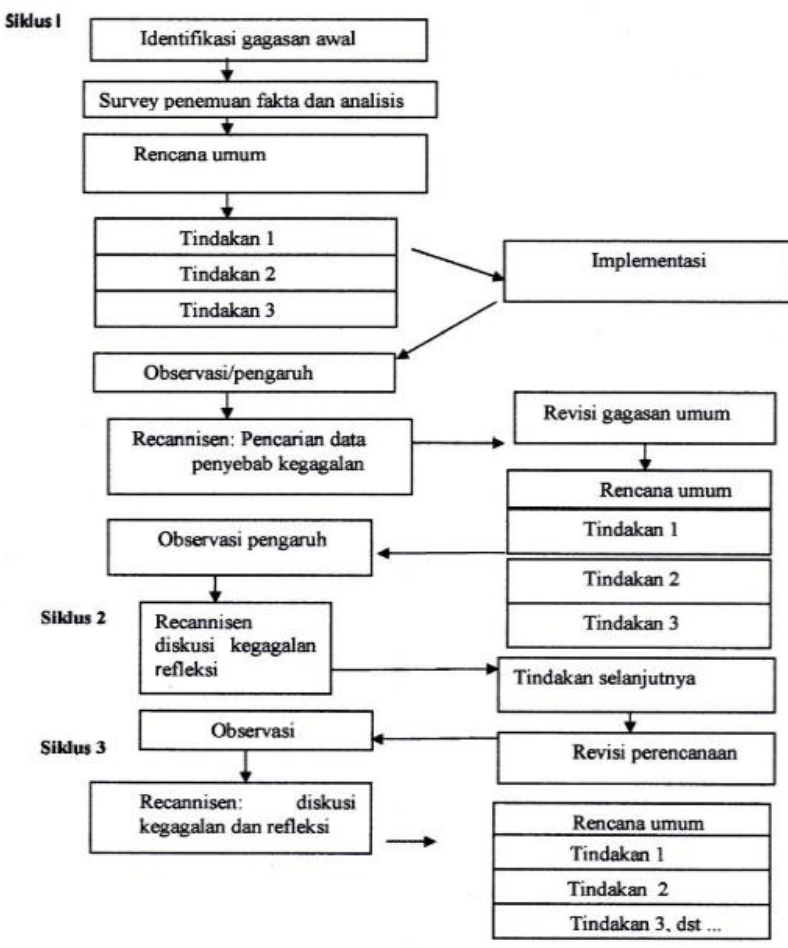

Gambar 1. Desain penelitian tindakan kelas berdasarkan adaptasi dari John Elliot 
Rencana tindakan ini disusun minimal untuk dua siklus sesuai dengan perkiraan terpecahnya masalah ini secara optimal yaitu 2 siklus namun apabila diperlukan dan nilai yang diinginkan belum tercapai, bisa dilanjutkan ke siklus-siklus berikutnya. Penelitian tindakan kelas di sini bersifat reflektif dengan melakukan tindakan yang tepat dan dilaksanakan secara kolaboratif (kerjasama) untuk memperbaiki atau meningkatkan hasil belajar dan Aktivitas siswa dengan penyajian pembelajaran melalui model pembelajaran yang berbeda (Mulyatiningsih [9]). Desain penelitian digambarkan dalam spiral penelitian tindakan kelas berdasarkan adaptasi dari John Elliot ditampilkan pada gambar 1 .

\section{HASIL DAN PEMBAHASAN}

Sebelum melakukan tindakan dalam penelitian, peneliti melakukan observasi awal di kelas. Hasil observasi menunjukkan bahwa ketika guru mengajar tentang Aransemen Musik Mancanegara adalah rata-ratanya 66,03 sedangkan KKM yang ditentukan 75 . Peserta didik yang mendapatkan nilai di atas KKM hanya 8 orang $(23,53 \%)$ sedangkan peserta didik yang mendapat nilai dibawah KKM 26 orang $(76,47 \%)$. Padahal materi Aransemen Musik Mancanegara bahasannya cukup banyak/luas, maka diputuskan untuk menggunakan media pembelajaran audio visual pada mata pelajaran Seni Budaya dalam materi Aransemen Musik Mancanegara.

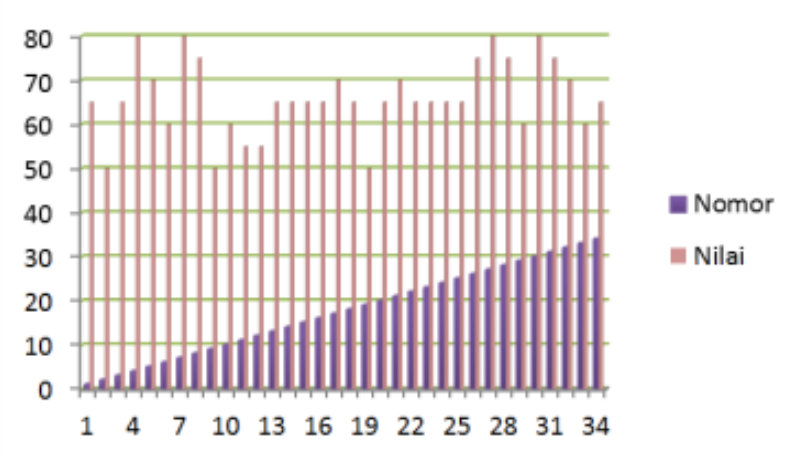

\section{Grafik 2. Data Hasil Belajar Peserta Didik Pada Pra Siklus}

Berdasarkan tabel dan grafik 2 terlihat bahwa peserta didik hanya memperoleh rata-rata 66,03 dengan nilai tertinggi 80 dan nilai terendah 50. Peserta didik yang hasil belajarnya diatas KKM hanya 8 orang atau $23,53 \%$ dari nilai KKM yang ditetapkan yaitu 75. Hal ini memberikan gambaran bahwa hasil belajar peserta didik pada mata pelajaran Seni Budaya masih tergolong rendah.

Sebelum menyusun rencana pembelajaran, peneliti melakukan identifikasi masalah dan merencanakan langkah-langkah yang akan dilaksanakan pada siklus I. Setelah peneliti mengetahui masalah dan langkah-langkah yang akan digunakan pada tindakan di siklus I, peneliti kemudian membuat Rencana Pelaksanaan Pembelajaran (RPP).
Menentukan pokok bahasan yang akan dijadikan materi bahasan pada penelitian. Mengembangkan Rencana Pelaksanaan Pembelajaran (RPP). Mengembangkan format evaluasi. Mengembangkan format observasi pembelajaran.

Pelaksanaan tindakan pada siklus I dilaksanakan dua kali pertemuan yaitu sebagai berikut:

1) Pelaksanaan pembelajaran pada pertemuan pertama Guru terlebih dahulu meneliti tingkat kesiapan peserta didik, mengecek absensi serta mengkondisikan kelas agar pembelajaran dapat berlangsung secara kondusif. Melakukan apersepsi dengan menampilakan suara musik. Selanjutnya guru meminta peserta didik untuk menyimak dan menanggapi musik yang diperdengarkan. Guru mendengarkan dan menayangkan musik melalui layar proyektor LCD. Peserta didik melakukan diskusi untuk mengerjakan lembar kerja yang telah disiapkan oleh guru. Peserta didik mempresentasikan hasil diskusi kelompok masing-masing. Guru menutup pelajaran dengan membimbing peserta didik melakukan diskusi secara klasikal untuk menarik kesimpulan dari materi yang telah dipelajari. Pada kegiatan ini peserta didik diberi kesempatan untuk menanyakan hal yang belum jelas dari materi yang telah dipelajari.

2) Pelaksanaan pembelajaran pada pertemuan kedua

Guru terlebih dahulu meneliti tingkat kesiapan peserta didik, mengecek absensi serta mengkondisikan kelas agar pembelajaran dapat berlangsung secara kondusif. Melakukan apersepsi dengan melakukan tanya jawab tentang materi yang telah dipelajari minggu lalu. Guru menayangkan film cara meng aresenmen musik. Selanjutnya peserta didik menyimak dan mengidentifikasi aresenmen musik. Peserta didik melakukan diskusi untuk mengerjakan lembar kerja yang telah disiapkan oleh guru. Peserta didik mempresentasikan hasil diskusi kelompok masing-masing. Guru menutup pelajaran dengan membimbing peserta didik melakukan diskusi secara klasikal untuk menarik kesimpulan dari materi yang telah dipelajari. Dengan kesempatan ini peserta didik diberi kesempatan untuk menanyakan hal yang belum jelas dari materi yang telah dipelajari. Guru melakukan uji kompetensi dengan tes tertulis

\section{Hasil Pengamatan/Observasi}

Dari hasil observasi siklus I, didapat bahwa dalam melaksanakan pembelajaran Seni Budaya tentang Aransemen Musik Mancanegara dengan menggunakan media pembelajaran audio visual pada siklus I, guru telah menerapkannya sesuai dengan Rencana Pelaksanaan Pembelajaran (RPP) yang telah disiapkan. Berdasarkan hasil pengamatan yang dilakukan oleh observer, guru terlalu cepat dalam menjelaskan. Masalah lain yang di dapat dari pengamatan observer adalah pada saat guru menjelaskan materi, masih ada peserta didik yang kurang memperhatikan.

Data mengenai keaktifan peserta didik dapat diperoleh dengan menggunakan lembar observer seperti pada lampiran. Keaktifan peserta didik tersebut dapat dilihat dalam hal bertanya dan menjawab pertanyaan dari guru maupun antusiasnya dalam mengerjakan latihan pada 
saat proses pembelajaran berlangsung. Jika digambarkan dalam bentuk grafik, maka data keaktifan siswa pada siklus 1 tersaji pada gambar 3 .

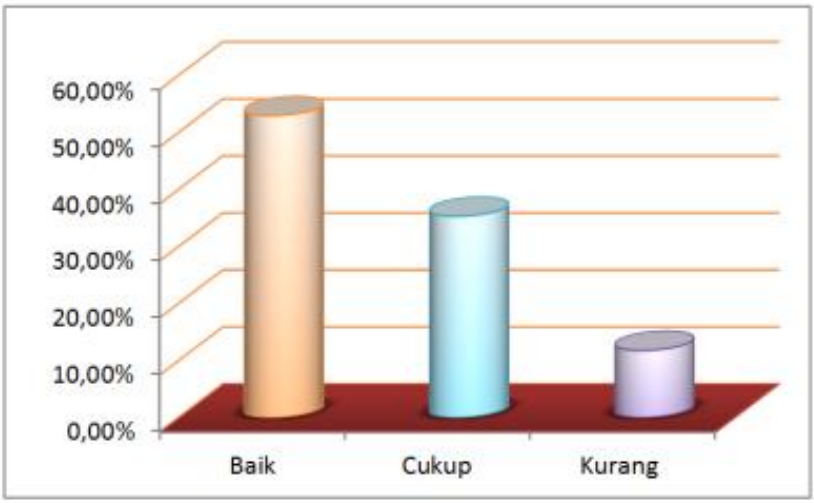

Gambar 3. Keaktifan Peserta Didik Pada Siklus 1

Data pada tabel dan grafik mengenai aktifitas peserta didik pada siklus I menunjukkan bahwa lebih dari setengahnya( $52,94 \%$ ) peserta didik baik dalam mengikuti KBM, kurang setengahnya $(35,29 \%)$ cukup mengikuti KBM dan kurang setengahnya $(11,77 \%)$ peserta didik kurang semangat mengikuti KBM.

\section{KESIMPULAN}

Bedasarkan hasil penelitian yang telah dilakukan di SMA Negeri 9 Kota Bogor pada peserta didik kelas XII IPA 3 Semester 1 tahun pelajaran 2017-1018 bahwa hasil belajar peserta didik sesudah menggunakan media pembelajaran audio visual menunjukkan hasil yang memuaskan. Dari uraian pada bab sebelumnya, dapat diambil simpulan sebagai berikut Media pembelajaran audio visual dapat meningkatan hasil belajar pesertsa didik pada materi Aransemen Musik Mancanegara di kelas XII IPA 3 SMA Negeri 9 Kota Bogor dengan menggunakan media pembelajaran audio visual Hasil belajar mata pelajaran Seni Budaya khususnya materi Aransemen Musik Mancanegara di kelas XII IPA 3 SMA Negeri 9 Kota Bogor sebelum menggunakan media pembelajaran audio visual mempunyai nilai rata-rata 66,03 .

Hasil penelitian ini dapat dijadikan sebagai bahan untuk program pembinaan sekolah dalam rangka meningkatkan kemampuan guru dalam melaksanakan KBM di masing-masing kelas, agar SMA Negeri 9 Kota Bogor menjadi sekolah percontohan dalam mengembangkan metode/model/media pembelajaran.

\section{REFERENSI}

[1] Syaiful dan Zain, Aswan. 2006. Strategi Belajar Mengajar. Jakarta: Rineka Cipta

[2] Bloom. 2001. Dasar-dasar Pendidikan. Surakarta: UNS.
[3] Agus Wibowo. 2012. Pendidikan Karakter: Strategi Membangun Karakter Bangsa Berperadaban. Yogyakarta: Pustaka Pelajar.

[4] N. Karmila and Y. Suchyadi, "Supervisi Pendidikan Di Sekolah Alam Bogor," J. Pendidik. dan Pengajaran Guru Sekol. Dasar, vol. 03, pp. 31-33, 2020.

[5] Ngalim Purwanto, M. 2004. Psikologi Pendidikan. Bandung: PT Remaja Rosdakarya.

[6] Poerwadarminta, 2002, Kamus Umum Bahasa Indonesia, Jakarta : Balai Pustaka

[7] Rahadi, Aristo. 2003. Media Pembelajran. Jakarta: Departemen Pendidikan Nasional Direktorat Jenderal Pendidikan Dasar danMenengah.

[8] Djamarah, Bahri Syaiful. 2004. Pola Komunikasi Orang Tua \& Anak Dalam keluarga. Jakarta: PT. Reneka Cipta.

[9] Mulyatiningsih, Endang. 2011. Metode Penelitian Terapan Bidang Pendidikan. Bandung: Alfabeta. 